\title{
Decreased Kinase Activity of Insulin Receptors from Adipocytes of Non-insulin-dependent Diabetic Subjects
}

Gary R. Freidenberg, Robert R. Henry, Harald H. Klein, Donna R. Reichart, and Jerrold M. Olefsky

Department of Medicine, University of California, San Diego, and Veterans Administration Medical Center, San Diego, California 92161

\begin{abstract}
The tyrosine kinase activity of the insulin receptor was examined with partially-purified insulin receptors from adipocytes obtained from 13 lean nondiabetics, 14 obese nondiabetics, and 13 obese subjects with non-insulin-dependent diabetes (NIDDM). Incubation of receptors at $4^{\circ} \mathrm{C}$ with $\left[\gamma-{ }^{32} \mathrm{P}\right] \mathrm{ATP}$ and insulin resulted in a maximal 10-12-fold increase in autophosphorylation of the 92-kDa $\beta$-subunit of the receptor with a half maximal effect at 1-3 $\mathrm{ng} / \mathrm{ml}$ free insulin. Insulin receptor kinase activity in the three experimental groups was measured by means of both autophosphorylation and phosphorylation of the exogenous substrate Glu4:Tyr1. In the absence of insulin, autophosphorylation and Glu4:Tyr1 phosphorylation activities, measured with equal numbers of insulin receptors, were comparable among the three groups. In contrast, insulin-stimulated kinase activity was comparable in the control and obese subjects, but was reduced by $\sim \mathbf{5 0 \%}$ in the NIDDM group. These findings indicate that the decrease in kinase activity in NIDDM resulted from a reduction in coupling efficiency between insulin binding and activation of the receptor kinase. The insulin receptor kinase defects observed in NIDDM could be etiologically related to insulin resistance in NIDDM and the pathogenesis of the diabetic state.
\end{abstract}

\section{Introduction}

It is well accepted that the binding of insulin to specific cell surface receptors activates certain transmembrane and intracellular signaling mechanisms important in coupling insulin binding to insulin action. The details of these proposed molecular signals have not been clarified, however it has been suggested that phosphorylation and dephosphorylation of cellular proteins may play a role (1-3). This notion has received support from in vitro studies showing that the highly purified insulin receptor is a heterotetrameric glycoprotein comprised of two subunits: an $\alpha$ subunit that contains the major insulin binding domain of the receptor, and a $\beta$ subunit that expresses insulin-stimulative kinase activity directed toward its own tyrosine residues (4-6). This autocatalytic reaction also serves to activate the insulin receptor kinase toward tyrosine-containing, nonreceptor substrates (710). These findings have been largely made in cell-free systems, however similar findings have been observed in intact cells. For example, Maller et al. (11) microinjected purified insulin receptors into frog oocytes and demonstrated that the injected recep-

Portions of this research were presented at the annual meeting of the Western Society of Clinical Investigation, February 1986.

Address correspondence to Dr. Gary R. Freidenberg, Veterans Administration Medical Center, Department of Medicine (V-151), 3350 La Jolla Village Drive, San Diego, CA 92161.

Received for publication 15 April 1986.

The Journal of Clinical Investigation, Inc.

Volume 79, January 1987, 240-250 tors mediated the phosphorylation of serine residues of S6 ribosomal protein. Additionally, treatment of intact hepatoma cells with insulin leads to a rapid increase in ${ }^{32} \mathrm{P}$ incorporation into the tyrosine residues of the receptor $\beta$ subunit $(12,13)$, and it has recently been noted that a 1-2 s exposure of intact adipocytes to insulin leads to a dose-dependent activation of the kinase function of the subsequently isolated insulin receptor (10). These combined results have led to the speculation that in intact cells, insulin binding rapidly activates the insulin receptor tyrosine kinase toward biologically important intracellular substrates, thereby coupling insulin binding to some or all of insulin's biologic effects.

In support of a role for the insulin receptor kinase in the biologic actions of insulin, several investigators have demonstrated altered kinase activity of insulin receptors isolated from humans and laboratory animals with altered insulin action. For example, Grunberger et al. (14) and Grigorescu et al. $(15,16)$ studied insulin binding and insulin receptor kinase activity in insulin receptors partially purified from cells of patients with severe insulin-resistant Type A diabetes. Their results in monocytes, erythrocytes, and cultured fibroblasts indicated that most patients with this disorder demonstrated a reduction in kinase activity. In some patients, this reduction was due to a reduction in insulin receptors but in others, it was due to a decrease in intrinsic kinase activity per receptor. In diabetic animals, Kadowaki et al. (17), using liver, and more recently Burant et al. (18), studying hindlimb muscle, found decreased intrinsic receptor kinase activity, in insulin receptors partially purified from experimentally diabetic rats. LeMarchand-Brustel et al. (19) found a similar reduction in kinase activity in skeletal muscle from mice rendered obese and diabetic by gold thioglucose administration. In another study, we reported decreased intrinsic kinase activity of hepatic insulin receptors after $3 \mathrm{~d}$ of fasting, a condition associated with reduced insulin action, and increased kinase activity in rats fed high-carbohydrate diets, a regimen that produces an increase in insulin action (20). Taken together, these studies suggest a possible role for the insulin receptor kinase in insulin action and indicate that alterations in receptor kinase activity may occur in states of insulin resistance.

Insulin resistance is a prominent feature of both human obesity (21-24) and non-insulin-dependent diabetes mellitus $(\text { NIDDM })^{1}(24-26)$. Some of this insulin resistance is accounted for by a reduction in insulin binding to its receptor, however the major component is attributed to a post-binding defect in insulin action. Defects have been described in the glucose transport system and at several intracellular metabolic sites in isolated adipocytes and skeletal muscle from subjects with both NIDDM $(25,27,28)$ and obesity (29-32). Studies in which insulin binding

1. Abbreviations used in this paper: BMI, body mass index; CTP, cytosine triphosphate; Glu4:Tyr1, poly (Glu-Tyr); KIU, kallikrein international unit; NIDDM, non-insulin-dependent diabetes mellitus; OGTT, oral glucose tolerance test; PMSF, phenylmethylsulfonyl fluoride. 
has been correlated with in vivo measurements of glucose disposal have revealed decreased coupling of insulin binding to action in NIDDM (33) but not obesity (22). This finding suggests that the insulin resistance of obesity differs from that of NIDDM.

The isolated adipocyte has proved a useful model to investigate insulin action in NIDDM and obesity. It is a well-studied target tissue for insulin, and adequate amounts of tissue for study can be obtained under local anesthesia. Moreover, the isolated adipocyte mirrors the insulin resistance observed in vivo $(25$, 32). Thus, we have utilized human adipose tissue to study insulin receptor kinase activity in control, obese, and NIDDM subjects.

\section{Methods}

Materials. Monocomponent porcine insulin and ${ }^{125} \mathrm{I}-\mathrm{Tyr}$ $\mathrm{A}^{14} \mathrm{]}$ monoiodoinsulin were generous gifts from Dr. Bruce Frank and Dr. Ronald Chance of the Eli Lilly \& Co., Indianapolis, IN. Serum from a patient with anti-insulin receptor antibodies was kindly supplied by Dr. Lawrence Mandarino, La Jolla, CA. $\left[\gamma-{ }^{32} \mathrm{P}\right] \mathrm{ATP}(3,000 \mathrm{Ci} / \mathrm{mmol})$ was purchased from Amersham Corp., Amersham, Buckinghamshire, England. Collagenase was obtained from Worthington Biochemical Corp., Freehold, NJ, bovine serum albumin (BSA) fraction V, from Armour Pharmaceutical Co., Chicago, IL, Protein A from Bethesda Research Laboratories, Gaithersburg, MD, wheat germ agarose beads from Vector Laboratories, Burlingame, CA, and aprotinin from Farbenfabriken Beyer $\mathrm{Ag}$ Pharmaceuticals, New York, NY. The following reagents were purchased from Sigma Chemical Co., St. Louis, MO: HEPES, Triton X$100, N$-acetyl-D-glucosamine, ATP, cytosine triphosphate (CTP), phenylmethylsulfonyl fluoride (PMSF), poly (Glu-Tyr) (Glu4:Tyr1), phosphoamino acid standards, and polyethylene glycol. All materials for protein determination and sodium dodecyl sulfate gel electrophoresis (SDS-PAGE) were from Bio-Rad Laboratories, Richmond, CA.

Patients. The study population consisted of 40 paid volunteers recruited on the basis of body weight, history of diabetes, fasting blood glucose, and results of prior glucose tolerance tests. All subjects were admitted to the Veterans Administration Medical Center in La Jolla, $\mathrm{CA}$, and informed consent was obtained. Subjects were given $3 \mathrm{~d}$ of a solid isocaloric diet followed by an overnight fast and a standard 75-g 4-h oral glucose tolerance test (OGTT). They were subsequently classified as having either normal glucose tolerance or NIDDM, based upon criteria established by the National Diabetes Data Group (34). Thirteen subjects had NIDDM, 27 had normal glucose tolerance. The subjects with NIDDM had a mean age ( \pm SEM) of $53.6 \pm 3.3 \mathrm{yr}$ and had evidence of overt diabetes for a mean duration of $12.2 \pm 2.4$ yr. Six were previously untreated, two had received previous insulin therapy, and five had been given sulfonylurea agents in the past (Table I). Among these subjects, insulin and sulfonylurea agents were withdrawn with consent at least 3 wk before entry into the study. Based upon relative body mass indices (BMI), all of the diabetic subjects were considered obese (BMI $=37.5 \pm 2.5$ $\mathrm{kg} / \mathrm{M}^{2}$ ). The nondiabetic subjects were also subdivided on the basis of BMI, and this group of 27 patients was comprised of 13 lean subjects

Table I. Patient Characteristics

\begin{tabular}{|c|c|c|c|c|c|}
\hline & \multirow[b]{2}{*}{ Number } & \multirow[b]{2}{*}{ Age } & \multirow[b]{2}{*}{ BMI } & \multicolumn{2}{|c|}{ Fasting serum } \\
\hline & & & & Glucose & Insulin \\
\hline & & $y r$ & $\mathrm{~kg} / \mathrm{M}^{2}$ & $m g / d l$ & $U / m l$ \\
\hline Control & 13 & $33.1 \pm 1.3$ & $22.9 \pm 0.5$ & $96 \pm 2$ & $11 \pm 3$ \\
\hline Obese & 15 & $46.5 \pm 3.4^{*}$ & $33.2 \pm 2.1^{*}$ & $97 \pm 4$ & $24 \pm 5$ \\
\hline NIDDM & 13 & $53.6 \pm 3.3^{*}$ & $37.0 \pm 0.5^{*}$ & $220 \pm 20^{*}$ & $25 \pm 3^{*}$ \\
\hline
\end{tabular}

$P<0.05$ compared with control

$* P<0.01$ compared with control
(BMI, $22.9 \pm 0.5 \mathrm{~kg} / \mathrm{M}^{2}$ ) with a mean age of $33.5 \pm 1.3 \mathrm{yr}$ and 14 obese subjects (BMI, $33.2 \pm 2.1 \mathrm{~kg} / \mathrm{M}^{2}$ ) whose average age was $46.5 \pm 3.4 \mathrm{yr}$. For purposes of dividing the nondiabetics into lean and obese groups, obesity was defined as BMI $>25 \mathrm{~kg} / \mathrm{M}^{2}$ (34).

Analytical methods. Insulin was assayed by a double-antibody radioimmunoassay according to the method of Desbuquois and Aurbach (35). Glucose levels were measured by the glucose oxidase method using a glucose analyzer (Yellow Springs Instrument Co., Yellow Springs, $\mathrm{OH}$ ).

Partial purification of insulin receptors from isolated human adipocytes. Adipose tissue (7-24 g) was obtained from the lower abdominal region after an overnight fast, as previously described (36). Isolated adipocytes were prepared by a modification (36) of the method of Rodbell (37). Following the preparation of freshly isolated adipocytes, an icecold solubilization mixture was added to the cells to yield final concentrations of $1.5 \%$ Triton X-100, $7.5 \mathrm{mg} / \mathrm{ml}$ bacitracin, $15 \mathrm{mM}$ benzamidine, 1,500 kallikrein international units $(\mathrm{KIU}) / \mathrm{ml}$ aprotinin, and 2.5 mM PMSF, pH 7.4. The cells were disrupted by vigorous mechanical agitation, and cell solubilization proceeded for $30 \mathrm{~min}$ at $4^{\circ} \mathrm{C}$. Under these conditions, $>90 \%$ of the insulin receptors are extracted. Following solubilization, the cellular extract was centrifuged for $10 \mathrm{~min}$ at $4^{\circ} \mathrm{C}$, the cellular lipid layer was removed, and the nonsoluble material was separated by centrifugation at $200,000 \mathrm{~g}$ for $15 \mathrm{~min}$ at $4^{\circ} \mathrm{C}$. The clarified extract was diluted 1:4 with buffer A, containing 25 mM HEPES (pH 7.4), $10 \%$ (wt/vol) glycerol, $0.05 \%$ Triton, $120 \mathrm{mM} \mathrm{NaCl}, 2.5 \mathrm{mM} \mathrm{KCl}$, $1 \mathrm{mM} \mathrm{CaCl}, 1 \mathrm{mM} \mathrm{MgCl}_{2}$, supplemented with $15 \mathrm{mM}$ benzamidine, $1,500 \mathrm{KJU} / \mathrm{ml}$ aprotinin, and $2.5 \mathrm{mM}$ PMSF, recycled twice over $0.75-$ $1.0 \mathrm{ml}$ of wheat germ agarose at $4^{\circ} \mathrm{C}$ with an average flow rate of 0.5 $\mathrm{ml} / \mathrm{min}$. The column was washed with 50 bed vol of buffer $\mathrm{A}$, and the glycoproteins were desorbed in $0.5 \mathrm{ml}$ fractions with buffer A containing $0.3 \mathrm{M} \mathrm{N}$-acetyl-D-glucosamine. Control studies demonstrated that of the insulin receptors applied to the wheat germ columns, $\sim 80 \%$ were recovered in two fractions for all experimental groups, as assessed by insulin binding activity. These fractions were then combined, aliquoted, and frozen at $-70^{\circ} \mathrm{C}$ for use in subsequent phosphorylation and insulin binding studies. The protein content of the frozen aliquots determined by the Bradford dye method (38) with the Bio-Rad Laboratories reagent was $0.297 \pm 0.02 \mathrm{mg} / \mathrm{ml}$ in the lean controls, $0.382 \pm 0.02$ in the nondiabetic obese, and $0.342 \pm 0.03$ in the diabetics.

Insulin-binding assays. Aliquots of the frozen receptor preparations were diluted to a protein concentration of $0.08-0.13 \mathrm{mg} / \mathrm{ml}$ and incubated in triplicate with [ ${ }^{125} \mathrm{I}-\mathrm{Tyr} \mathrm{A}^{14}$ ]insulin (final concentration, $0.5 \mathrm{ng} / \mathrm{ml}$ ) at $4^{\circ} \mathrm{C}$ for $18 \mathrm{~h}$ in the absence and presence of increasing concentrations of unlabeled insulin in a total volume of $40 \mu \mathrm{l}$ as previously described (20). The amount of receptor-bound hormone was determined by precipitation with polyethylene glycol. Nonspecific binding, defined as the amount of radioactivity precipitated in the presence of $5,000 \mathrm{ng} / \mathrm{ml} \mathrm{un}$ labeled insulin, was subtracted from total binding at each insulin concentration, and accounted for $<3 \%$ of the total radioactivity added to each assay tube. As a measure of the number of insulin receptors in each frozen receptor preparation, the insulin-binding capacity was determined by estimating the $x$ intercept of Scatchard plots of the insulin binding data. Degradation of insulin during the binding assays, as assessed by determining the percent of unbound radioactivity soluble in $5 \%$ trichloroacetic acid, was $<2 \% / 18 \mathrm{~h}$ at $4^{\circ} \mathrm{C}$ for all receptor preparations.

Insulin receptor autophosphorylation. In all experiments that assessed insulin receptor kinase activity, lectin-purified receptor preparations were first diluted in buffer $\mathrm{A}$, containing $N$-acetyl-D-glucosamine, to $0.95 \mathrm{fmol} /$ $\mu l$ insulin-binding activity, the receptor density of the least concentrated receptor preparation among the $\mathbf{4 0}$ subjects. This procedure permitted all subsequent phosphorylation assays to be performed using equal numbers of receptors for all subjects. Aliquots $(80 \mu \mathrm{l})$ of the adjusted receptor preparations were preincubated in the absence and presence of 2,5 , and $500 \mathrm{ng} / \mathrm{ml}$ (final concentrations) of unlabeled insulin in a total volume of $90 \mu \mathrm{l}$. After $18 \mathrm{~h}$ at $4^{\circ} \mathrm{C}$, the phosphorylation reaction was initiated by the addition of $20 \mu \mathrm{l}$ of a reaction mixture calculated to give final concentrations of $5 \mathrm{mM} \mathrm{MnCl}_{2}, 4 \mathrm{mM} \mathrm{MgCl}_{2}, 500 \mu \mathrm{M} \mathrm{CTP}$, and 50 $\mu \mathrm{M}\left[\gamma-{ }^{32} \mathrm{P}\right] \mathrm{ATP}(\sim 11 \mu \mathrm{Ci} / \mathrm{nmol})$. After incubation at $4^{\circ} \mathrm{C}$ for various periods of time, the reaction was terminated by the addition of a solution 
designed to yield final concentrations of $25 \mathrm{mM}$ HEPES ( $\mathrm{pH} 7.6$ ), $0.05 \%$ Triton, $10 \%$ glycerol, $2 \mathrm{mM}$ sodium orthovanadate, $100 \mathrm{mM} \mathrm{NaF}, 1$ $\mathrm{mM}$ PMSF, $5 \mathrm{mM}$ EDTA, $50 \mathrm{mM}$ ATP, and $10 \mathrm{mM}$ sodium pyrophosphate.

Immunoprecipitation assay. The phosphorylated insulin receptors were immunoprecipitated by incubation with a 1:50 dilution of serum containing human anti-insulin receptor antibodies. After $12 \mathrm{~h}$ at $4^{\circ} \mathrm{C}$, $80 \mu \mathrm{l}$ of protein $\mathrm{A}$, made $20 \%$ (wt/vol) in buffer containing $145 \mathrm{mM}$ $\mathrm{NaCl}, 2.6 \mathrm{mM} \mathrm{KH}_{2} \mathrm{PO}_{4}, 10.9 \mathrm{mM} \mathrm{Na} \mathrm{HPO}_{4}$, and $0.5 \%$ Triton, was added and incubated for $1.5 \mathrm{~h}$ at $4^{\circ} \mathrm{C}$. The pellets, obtained after centrifugation, were boiled in (final concentrations) $10 \%$ glycerol, $100 \mathrm{mM}$ dithiothreitol, $2 \%$ SDS, $0.05 \%$ bromophenol blue, and $0.5 \mathrm{M}$ Tris base (pH 6.8). The resulting supernatants were subjected to SDS-PAGE on $7.5 \%$ resolving gels according to the method of Laemmli as previously outlined (20). The $\beta$ subunit of the insulin receptor, located by autoradiography performed at $-70^{\circ} \mathrm{C}$ with $\mathrm{AR}$ film (Eastman Kodak Co., Rochester, NY) and lighting (DuPont Co., Wilmington, DE) plus intensifying screens, was excised from the dried gels and counted by scintillation. Equal areas of dried gel, judged free of radioactivity by autoradiography, were cut, counted, and subtracted as background. Under these experimental conditions, control studies showed that $90-95 \%$ of the phosphorylated receptors were immunoprecipitated. Molecular weight standards were: myosin $\left(M_{\mathrm{r}}, 200,000\right), \beta$-galactosidase $\left(M_{\mathrm{r}}, 116,000\right)$, phosphorylase b $\left(M_{\mathrm{r}}, 97,000\right)$, BSA $\left(M_{\mathrm{r}}, 68,000\right)$, and ovalbumin $\left(M_{\mathrm{r}}\right.$, 45,000).

Artificial substrate phosphorylation. Aliquots $(30 \mu \mathrm{l})$ of receptor preparations, adjusted to equivalent amounts of insulin-binding activity were preincubated in the absence and presence of $2.5,10$, and $500 \mathrm{ng} /$ $\mathrm{ml}$ unlabeled insulin for $18 \mathrm{~h}$ at $4^{\circ} \mathrm{C}$ in a total volume of $40 \mu \mathrm{l}$. To initiate the phosphorylation reaction, $10 \mu \mathrm{l}$ of the exogenous substrate Glu4:Tyrl (final concentration, $2 \mathrm{mg} / \mathrm{ml}$ ) and $10 \mu \mathrm{l}$ of a mixture calculated to give final concentrations of $5 \mathrm{mM} \mathrm{MnCl}, 12 \mathrm{mM} \mathrm{MgCl}$, $500 \mu \mathrm{M} \mathrm{CTP}$, and $50 \mu \mathrm{M}\left[\gamma^{-32} \mathrm{P}\right] \mathrm{ATP}(\sim 5 \mu \mathrm{Ci} / \mathrm{nmol})$ were added. After incubation at $4^{\circ} \mathrm{C}$ for different intervals of time, the reaction was terminated by the addition of $50 \mathrm{mM}$ ATP, and the ${ }^{32} \mathrm{P}$ incorporated into Glu-Tyr was determined by the filter paper method, as previously described (39). Radioactivity, measured in the absence of peptide, was used to assess the background and generally was $<10 \%$ of the basal activity measured in the presence of peptide.

Measurement of ATPase activity. Insulin receptor preparations were preincubated with $500 \mathrm{ng} / \mathrm{ml}$ insulin under conditions identical to those described for the autophosphorylation reactions. Additional incubates without receptors were prepared using buffer A with $0.3 \mathrm{M} \mathrm{N}$-acetyl-Dglucosamine. After $18 \mathrm{~h}$ at $4^{\circ} \mathrm{C},\left[\gamma-{ }^{32} \mathrm{P}\right] \mathrm{ATP}(50 \mu \mathrm{M}, 1 \mu \mathrm{Ci}), 5 \mathrm{mM}$ $\mathrm{MnCl}_{2}$ and $4 \mathrm{mM} \mathrm{MgCl}$ were added, with and without $500 \mu \mathrm{M} \mathrm{CTP}$ (final concentration). $10-\mu \mathrm{l}$ aliquots were withdrawn at various times and added to $2 \mathrm{ml}$ of $50 \mathrm{mM} \mathrm{KH}_{2} \mathrm{PO}_{4}$ containing $0.1 \mathrm{~g}$ Norit A charcoal. The reaction mixture was vigorously vortexed and the charcoal pelleted by centrifugation $(500 \mathrm{~g}, 5 \mathrm{~min})$. The percent of total radioactivity remaining in the charcoal-free supernatant was taken as ${ }^{32} \mathrm{P}$ hydrolyzed from ATP (40).

Photolabeling of NAPA- ${ }^{125}$ I-insulin to intact adipocytes. Freshly isolated adipocytes, $\mathrm{pH} 7.4$, were incubated at $16^{\circ} \mathrm{C}$ for $30 \mathrm{~min}$ with a saturating concentration $(40 \mathrm{ng} / \mathrm{ml})$ of the photoactive compound NAPA- ${ }^{125}$ I-insulin in the presence or absence of an excess amount of unlabeled insulin after which the cells were exposed to UV radiation $(336 \mathrm{~nm})$ for $3 \mathrm{~min}$ at $4^{\circ} \mathrm{C}$ to effect chemical crosslinking, as previously detailed (41). Noncovalently bound NAPA-insulin was subsequently removed by washing, and the cells were solubilized and boiled in (final concentrations) $1.5 \% \mathrm{SDS}, 0.5 \mathrm{mM} N$-ethylmaleimide, and $1 \mathrm{mM}$ PMSF in the absence and presence of $100 \mathrm{mM}$ dithiothreitol. The proteins were analyzed on a 5-15\% continuous SDS-polyacrylamide gel, and the labeled proteins were located by autoradiography.

Data analysis. All values are given as the mean \pm SEM. Repeated measures, two-way analysis of variance and Duncan's multiple range test were employed for statistical evaluation of the results of the glucose tolerance tests and receptor kinase studies in the three experimental groups. For all other measurements, the Student's $t$ test was used.

\section{Results}

The characteristics of the subjects are displayed in Table I. Obese and NIDDM subjects were significantly older $(P<0.01)$ and fatter $(P<0.01)$ than the lean controls but were not statistically different in age or BMI from each other. Fasting levels of glucose were elevated relative to control subjects only in the NIDDM group. Fasting levels of insulin were elevated relative to controls in both the NIDDM and obese subjects. The full results of the oral glucose tolerance tests used to classify subjects as diabetic or nondiabetic are illustrated in Fig. 1.

Insulin binding. The insulin binding capacity of the partially purified lectin preparations of the three experimental groups is shown in Fig. 2. The amount of insulin bound at all concentrations of added insulin was nearly $50 \%$ less per milligram protein in the obese diabetics relative to either the lean or obese nondiabetic controls. The mean total insulin binding capacity of each preparation, calculated from the apparent $x$ intercept of each individual Scatchard plot, was $52 \%$ less $(P<0.01)$ in the NIDDM subjects, as illustrated in the inset to Fig. 2, relative to the controls. The binding capacity tended to be lower in the obese compared with the control group but this difference was not statistically significant. The decrease in receptor number in the NIDDM subjects occurred with no change in receptor affinity as indicated by the parallel, curvilinear plots in all three groups. The fall in receptor number but not in affinity noted in this cellfree system is consistent with similar findings previously reported by investigators studying intact human monocytes $(42,43)$ and adipocytes $(25,28)$. The approximate yield of receptors recovered per gram of fat was lower in both the obese and NIDDM subjects compared with the controls ( $\sim 246 \mathrm{fmol}$ insulin-binding capacity $/ \mathrm{g}$ in controls, $\sim 124 \mathrm{fmol} / \mathrm{g}$ in the obese, and $\sim 99 \mathrm{fmol} / \mathrm{g}$ in the NIDDM subjects). Thus, to obtain similar numbers of total receptors, more fat was generally extracted from the obese and NIDDM subjects than from the lean controls $(10.3 \pm 0.7 \mathrm{~g}$ in controls, $16.8 \pm 1.3$ in obese, and 15.8 \pm 1.4 in NIDDM). The process of partial purification of insulin receptors entails the use of wheat germ agglutinin, a lectin capable of adsorbing the insulin receptor and other sialated glycoproteins that are then eluted with $N$-acetylglucosamine and quantitated in the standard pro-
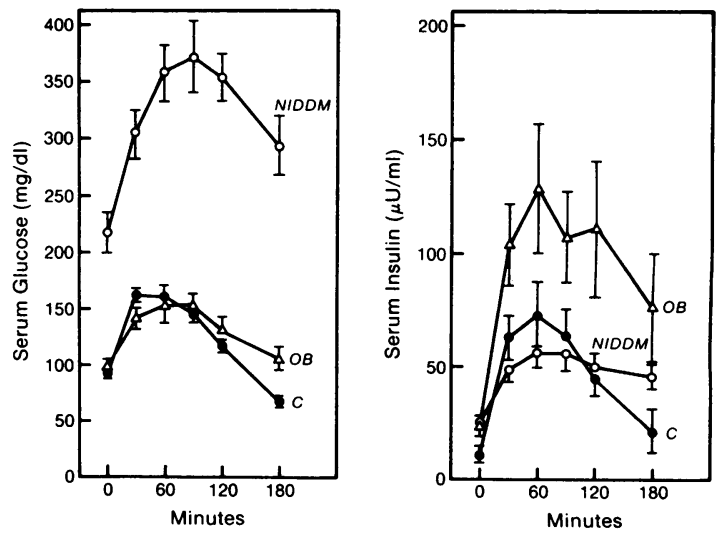

Figure 1. Oral glucose tolerance tests in the study population. 13 lean and 27 obese subjects were given $75 \mathrm{~g}$ glucose orally at time zero. Serial glucose and insulin levels were obtained. The subjects were then classified as nondiabetic lean (solid circle), non-diabetic obese (open triangle), or diabetic obese (open circle) according to established criteria (35). 


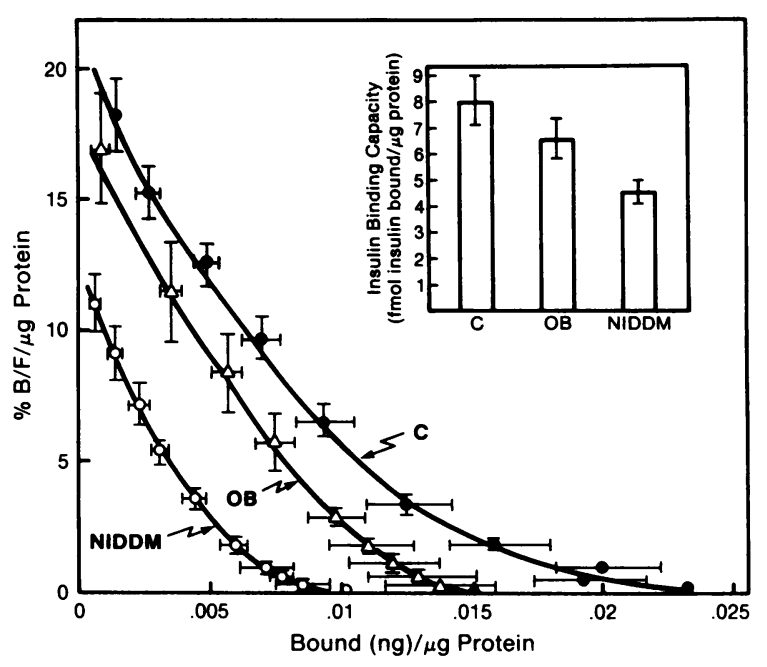

Figure 2. Insulin binding to control, obese, and NIDDM subjects. Aliquots $(20 \mu \mathrm{l})$ of receptor preparations from 13 control (solid circle), 14 obese (open triangle), and 13 NIDDM (open circle) subjects were used to measure insulin binding as described in Methods. (Main panel) Scatchard plots of the insulin binding data are plotted as the mean ( \pm SEM) of the binding data at each concentration of added insulin (Inset) total insulin binding capacities determined by estimation of the apparent $x$ intercept of individual Scatchard plots drawn for each subject.

tein assay. The yield of glycoproteins ( $\mu \mathrm{g})$ recovered in this manner per gram of fat was $\sim 25 \%$ less in the obese $(22.4 \pm 1.2 \mu \mathrm{g} /$ $\mathrm{g})$ and NIDDM $(22.1 \pm 1.5 \mu \mathrm{g} / \mathrm{g})$ subjects relative to the controls $(29.8 \pm 1.4 \mu \mathrm{g} / \mathrm{g})$. Thus, the amount of insulin receptor recovered per gram of fat was much less for the obese and NIDDM subjects, whereas the final yield and concentrations of insulin receptors per microgram of recovered glycoproteins was somewhat less than control $(19 \%$, NS) for the obese, and markedly less (52\%, $P<0.01)$ for the NIDDM. The modest reduction in receptor number in the obese group, noted in this cell-free system, contrasts with previous reports showing a greater reduction in intact adipocytes (21-24). Expression of receptor number in terms of recovered glycoprotein in the current study and cell number in other studies most likely accounts for these differences.

Insulin-stimulated autophosphorylation. When wheat germpurified receptors were preincubated with increasing concentrations of insulin, and then exposed to $\left[\gamma-{ }^{32} \mathrm{P}\right] \mathrm{ATP}$, there was an insulin-dependent increase in the amount of ${ }^{32} \mathrm{P}$ incorporated into a $\sim 92,000-$ mol wt protein as shown in Fig. $3 A$ for a control subject. By virtue of the insulin-dependent increase in labeling, its immunoprecipitability with anti-insulin receptor antibodies, and the close similarity of its apparent molecular weight to that reported for other cell types, this protein was identified as the $\beta$ subunit of the insulin receptor. When the bands corresponding to the $\beta$ subunit were excised and counted, a dose-response curve for insulin stimulation of autophosphorylation was constructed for three control subjects as shown in Fig. $3 B$. Insulin increased the incorporation of ${ }^{32} \mathrm{P}$ into the $\beta$ subunit by $10-12$-fold. The half-maximal effect of insulin occurred at $2.9 \pm 0.2 \mathrm{ng} / \mathrm{ml}$ with a maximal effect by $50-100 \mathrm{ng} / \mathrm{ml}$ added insulin. Basal autophosphorylation measured in the absence of insulin accounted for $8.2 \pm 2.2 \%$ of maximally insulin-stimulated autokinase activity. As reported by previous investigators, ligand occupancy is the major determinant of the state of phosphorylation of each
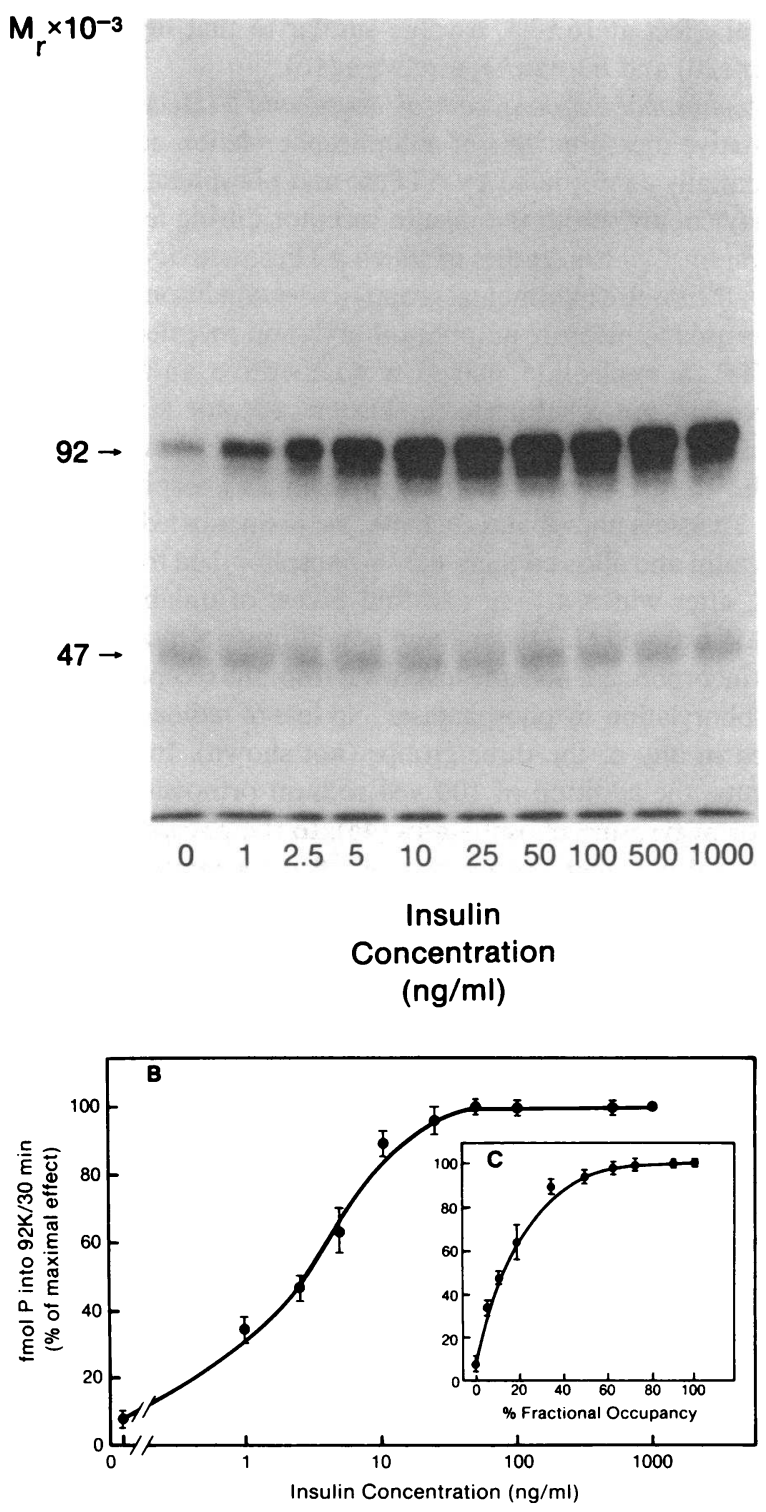

Figure 3. Dose response of autophosphorylation of insulin receptors from human adipocytes. Aliquots of wheat germ-purified receptors from three lean nondiabetic subjects were preincubated in the presence and absence of increasing concentrations of unlabeled insulin, with or without $0.5 \mathrm{ng} / \mathrm{ml}^{125} \mathrm{I}$-insulin. After $18 \mathrm{~h}$ at $4^{\circ} \mathrm{C}$, autokinase and insulin bindings assays were performed as described in Methods. (Upper panel) representative autoradiograph of insulin-stimulated autophosphorylation from a control subject. (Lower panel; $B$ ) The phosphorylated proteins corresponding to $M_{\mathrm{r}} 92,000$ were located by autoradiography, excised, and counted. The amount of phosphate incorporated into the $92-\mathrm{kD}$ band, expressed as the percent of the maximal effect achieved at $1,000 \mathrm{ng} / \mathrm{ml}$ insulin, is plotted as a function of increasing concentrations of added insulin. $(C)$ kinase data from $(B)$ redrafted as a function of the fraction of total receptors occupied with insulin at each concentration of added insulin as determined by Scatchard plots of the binding data.

receptor (44). To emphasize this relationship, the phosphorylation data of Fig. $3 B$ were recast as a function of fractional receptor occupancy (Fig. $3 \mathrm{C}$ ) rather than the concentration of added insulin. As can be seen, the plot of autophosphorylation is curvilinear with respect to receptor occupancy, with a half- 
maximal effect at $16 \pm 3 \%$, a value similar to that reported for rat liver (20) and human erythrocytes (16).

Autophosphorylation in control, obese, and NIDDM subjects. Quantitative measurements of autophosphorylation activity can be potentially confounded by ATPase and phosphatase activity that may copurify with the insulin receptor during lectin chromatography. Control studies in which ATPase activity was measured in the three experimental groups under conditions identical to those used to measure autophosphorylation revealed that 500 $\mu \mathrm{M}$ CTP, a nucleotide that is a competitive antagonist of ATPases but not a substrate for insulin receptor kinase (45), reduced the hydrolysis of ATP from $7.1 \pm 0.9 \% / 120 \mathrm{~min}$ to only $\sim 1 \% / \mathrm{h}$. Thus, CTP was routinely used in all phosphorylation assays. To assess phosphatase activity, we preincubated receptors with insulin and allowed them to self-phosphorylate for $120 \mathrm{~min}$ at $4^{\circ} \mathrm{C}$, after which a thousand-fold excess of unlabeled ATP $(50 \mathrm{mM})$ was added. Under these conditions no more labeled ATP is incorporated, and any loss of ${ }^{32} \mathrm{P}$ from the receptor reflects dephosphorylation by phosphatases. No loss of radioactivity was detected in any of the three groups (not shown). In other experiments, the addition of $100 \mu \mathrm{M}$ sodium orthovanadate, an inhibitor of tyrosine phosphatases (46), to the phosphorylation mixture did not alter the amount of ${ }^{32} \mathrm{P}$ incorporated into the receptors (not shown). Together, these results indicate that under the conditions of our assays, phosphatase activity was negligible in all three receptor preparations. We (20) and others (47) have shown a similar absence of tyrosine phosphatase activity in wheat germ-purified receptors from rat liver measured at $4^{\circ} \mathrm{C}$.

Having excluded potential interference from phosphatases and ATPases, insulin receptor autokinase activity was then compared among the three groups. Fig. $4 \mathrm{~A}$ illustrates the time dependency of autophosphorylation in control, obese, and NIDDM subjects. Equal numbers of insulin receptors in all three groups were preexposed to a maximally stimulating concentration of insulin. Subsequent autophosphorylation in all three groups was linear for $\sim 30 \mathrm{~min}$, with half-maximal incorporation of ${ }^{32} \mathrm{P}$ by $30-35 \mathrm{~min}$, and a maximal effect by $\sim 120 \mathrm{~min}$. At all times, the amount of ${ }^{32} \mathrm{P}$ incorporated into the $\beta$ subunit of
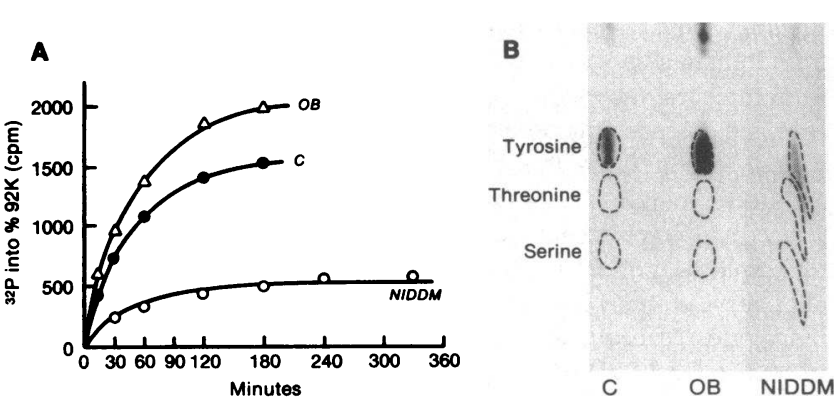

Figure 4. Autophosphorylation of the $\beta$ subunit of insulin receptors from control, obese, and NIDDM subjects. $(A)$ Time course of autophosphorylation. Aliquots of receptor preparations $(50 \mathrm{fmol}$ insulin binding activity) from each group were preincubated with $500 \mathrm{ng} / \mathrm{ml}$ insulin for $18 \mathrm{~h}$ at $4^{\circ} \mathrm{C}$. Autophosphorylation and immunoprecipitation were performed as noted in Methods, and the reactions were terminated at the indicated times. The amount of ${ }^{32} \mathrm{P}$ incorporated into the $92-\mathrm{kD}$ band at each time is plotted as counts per minute for one control (solid circle), obese (open triangle), and NIDDM (open circle) subject. (B) Phosphoamino acid analysis of autophosphorylation. Phosphoamino acid analysis was performed with phosphorylated receptors from $(A)$ as previously described (12). the receptor was similar in the control and obese subjects but reduced by $>50 \%$ in the NIDDM subjects. Phosphorylation reactions in intact cells exposed to insulin have documented that phosphorylation of both tyrosine and serine residues in the $\beta$ subunit occurs, whereas tyrosine residues are phosphorylated predominantly in cell-free systems (12). To assess phosphorylation patterns in the human adipocyte receptor systems, phosphoamino acid analysis was performed with receptors autophosphorylated in vitro in the presence of insulin. As shown in Fig. $4 \mathrm{~B},{ }^{32} \mathrm{P}$ incorporation occurred exclusively on tyrosine residues in all three groups.

In addition to this comparison of maximal insulin-stimulated ${ }^{32} \mathrm{P}$ incorporation, autophosphorylation was also measured over a range of insulin concentrations, and the results are displayed in Fig. 5. In the absence of insulin, basal autophosphorylation was not significantly different among the three groups (control, $1.73 \pm 0.24$; obese, $1.65 \pm 0.28$; NIDDM, $1.47 \pm 0.37$ fmol phosphate/76 fmol insulin-binding activity) and was subtracted from all corresponding values measured in the presence of different concentrations of insulin. Analyzed in this manner, the results displayed in Fig. 5 reflect only insulin-stimulated autophosphorylation. When equal amounts of insulin receptors were allowed to autophosphorylate, the amount of phosphate incorporated into the $\beta$ subunit of the receptor was similar in the lean controls and nondiabetic obese subjects at all insulin concentrations. In contrast, the amount of autophosphorylation was markedly reduced $(P<0.01$ by two-way analysis of variance) over a range of insulin concentrations in the NIDDM subjects relative to the two other groups. The concentration of insulin that produced a half-maximal stimulation of autophosphorylation was comparable in the three groups and occurred at $2.8 \pm 0.2,3.0 \pm 0.3$, and $3.2 \pm 0.2 \mathrm{ng} / \mathrm{ml}$ in the control, obese, and NIDDM, respectively. At maximally stimulating concentrations of insulin, the mean autokinase activity of the receptors from NIDDM was $46 \%(P<0.05)$ less than in the lean controls and $43 \%$ less $(P<0.05)$ than the obese nondiabetics.

Autophosphorylation activity is determined by measuring the amount of ${ }^{32} \mathrm{P}$ incorporated into the $\beta$ subunit of the receptor.

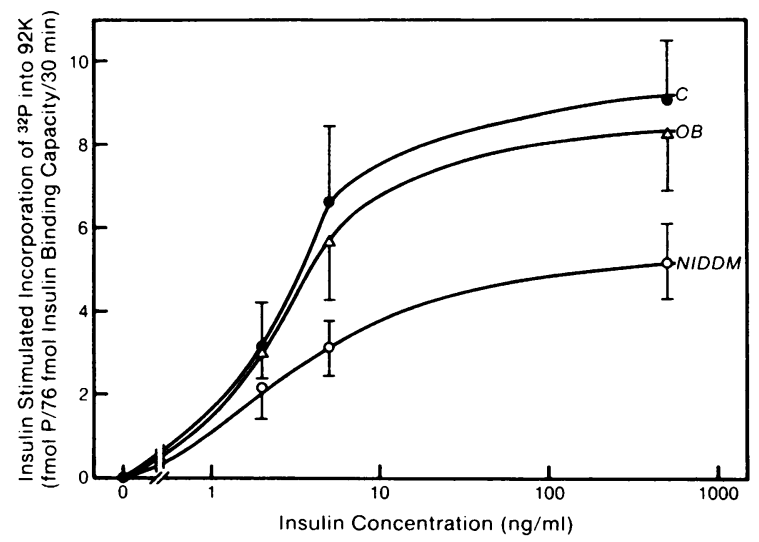

Figure 5. Insulin dose response of autophosphorylation. Aliquots of receptor preparations ( $76 \mathrm{fmol}$ insulin-binding capacity $/ 80 \mu \mathrm{l}$ ) were preincubated with $0,2,5$, or $500 \mathrm{ng} / \mathrm{ml}$ insulin after which autokinase reactions were conducted for $30 \mathrm{~min}$ at $4^{\circ} \mathrm{C}$. For each subject, the amount of ${ }^{32} \mathrm{P}$ incorporated into $92 \mathrm{kD}$ in the absence (basal) of insulin was subtracted from all corresponding values measured in the presence of insulin. The results are graphed as the mean $( \pm S E M)$ increase over basal from 10 control (solid circle), 13 obese (open triangle), and 13 NIDDM (open circle) subjects. 
Comparisons of autophosphorylation capacity among different receptor preparations should therefore take into account the number of $\beta$ subunits in each preparation. The results of autophosphorylation, as displayed in Fig. 5, were obtained from experiments in which equal amounts of insulin-binding activity were used for all subjects. Because insulin binds to the $\alpha$ subunit of the receptor, this approach to normalization assumes that every $\alpha$ subunit capable of binding insulin is also linked to a $\beta$ subunit. To assess this assumption, we used the photoactive compound NAPA- ${ }^{125}$ I-insulin to covalently crosslink labeled insulin to intact adipocytes from NIDDM subjects. The results, shown in Fig. 6, demonstrate a specifically labeled band, at 430 $\mathrm{kD}$, corresponding to the molecular weight of the intact insulin receptor $\left(\alpha_{2} \beta_{2}\right)$ heterodimer. No bands corresponding to the molecular weights of smaller receptor oligomers $\left(\alpha_{2} \beta_{1}, \alpha_{2}\right)$ or free $\alpha$ subunits were detected. Only upon addition of dithiothreitol, a reducing agent capable of splitting the sulfhydryl bonds connecting $\alpha$ and $\beta$ subunits of the intact receptor, were free $\alpha$ subunits seen. Previously, we have reported similar findings in adipocytes of controls (41). Thus, it appears that all $\alpha$ subunits were structurally linked to $\beta$ subunits in the receptor preparations, thus validating the use of insulin binding capacity to normalize insulin receptor kinase activity.

Exogenous substrate (Glu4:Tyrl) phosphorylation. The autocatalytic event that leads to self-phosphorylation of the insulin receptor renders the receptor an active tyrosine kinase toward exogenous substrates (7). As we have recently shown, relative insulin receptor kinase activity toward exogenous substrates may be different from that observed with autophosphorylation (20). Thus, we also measured receptor kinase activity with the exogenous substrate Glu4:Tyr1 as the phosphoacceptor. The time

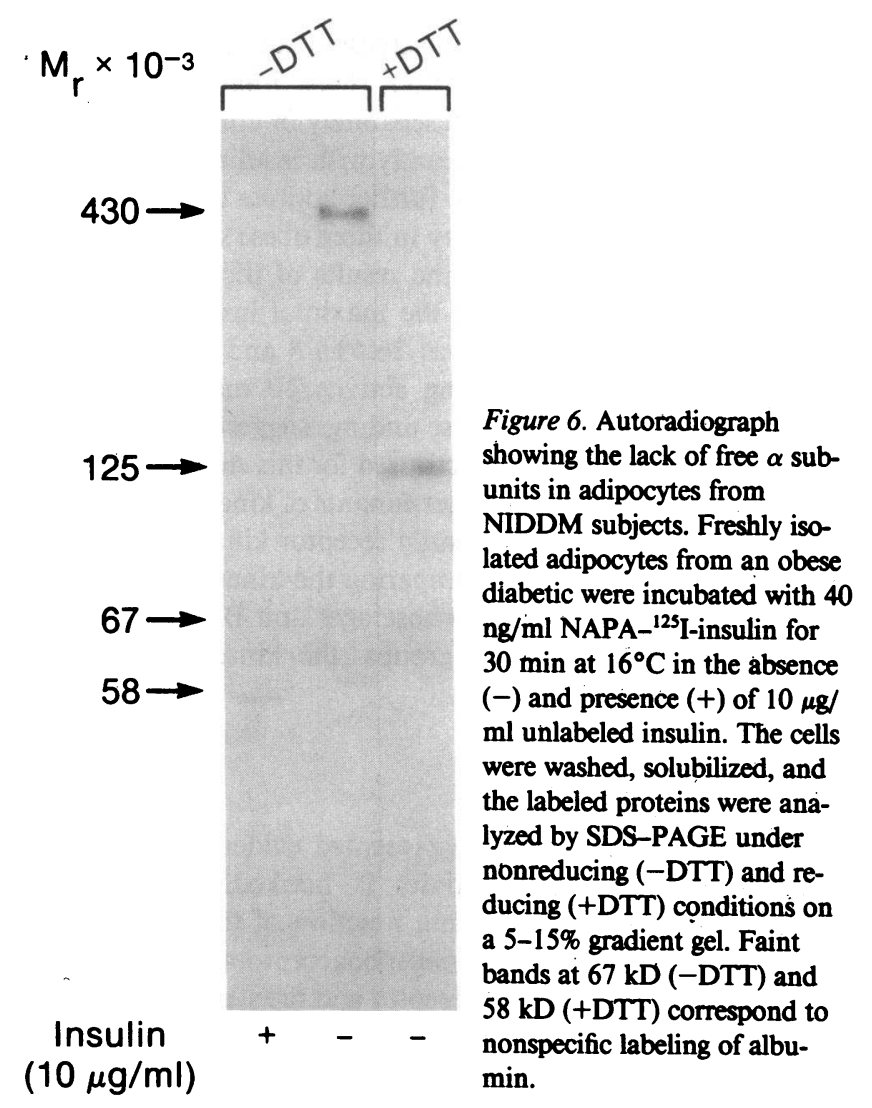

course of insulin-stimulated phosphorylation of Glu4:Tyr1 was measured using equal numbers of receptors from all three groups. The results, demonstrated in Fig. 7, revealed linear phosphorylation rates for $2-3 \mathrm{~h}$ in all three groups, but the rate of Glu4: Tyr1 phosphorylation was significantly slower in the NIDDM subjects compared with the control and obese, nondiabetic subjects. A full insulin dose-response curve for Glu4:Tyr1 phosphorylation is illustrated in Fig. 8. When equal amounts of receptors from the three groups were allowed to phosphorylate Glu4:Tyr1 in the absence of insulin, basal values were not significantly different (control, 47.6 \pm 3.9 ; obese, 46.2 \pm 5.7 ; NIDDM, 40.7 $\pm 6.0 \mathrm{fmol}$ phosphate/fmol insulin-binding activity/40 min) and these values were subtracted from the corresponding insulinstimulated values. Therefore, the results, displayed in Fig. $8 \mathrm{~A}$, directly illustrate the ability of insulin to augment Glu4:Tyr1 kinase activity over basal. Insulin-stimulated phosphorylation of Glu4:Tyr 1 was similar in the controls and nondiabetic obese groups but was significantly reduced $(P<0.01$ by two-way analysis of variance) in the NIDDM subjects over the entire range of insulin concentrations. At maximally stimulating concentrations of insulin, the mean increase in Glu4:Tyr 1 phosphorylation over basal was $33 \%$ less $(P<0.05)$ in the NIDDM group than in controls. The concentration of insulin causing half-maximal phosphorylation of Glu4:Tyr1 is most easily seen after recasting the insulin-stimulated kinase data of Fig. $8 \mathrm{~A}$ as a function of the percent of maximal effect. The results illustrated in Fig. 8 $B$, indicate that 3.6-fold more $(P<0.001)$ insulin was required to achieve a half-maximal effect in the NIDDM subjects than in either the control or obese subjects (control, 3.0 \pm 0.4 ; obese, 3.0 \pm 0.3 ; NIDDM, $11.0 \pm 0.4 \mathrm{ng} / \mathrm{ml}$ ).

These results are expressed in terms of the concentration of total insulin added to the preincubation mixture. However, as we have reported previously (20), kinase data are more appropriately expressed as a function of the concentration of free insulin, because it is the concentration of free, and not total added, insulin that determines receptor occupancy. Furthermore, in a cell-free system such as ours, where relatively large numbers of insulin receptors are used to measure kinase activity, total added insulin may significantly overestimate the free insulin concentration, particularly at low concentrations of total insulin. When the kinase data from Fig. $8 \mathrm{~B}$ were recalculated in terms of free insulin concentrations, the half-maximal effect occurred at $1.1 \pm 0.2 \mathrm{ng} / \mathrm{ml}$ in the controls, $1.0 \pm 0.3 \mathrm{ng} / \mathrm{ml}$ in the obese, and $6.2 \pm 0.3 \mathrm{ng} / \mathrm{ml}$ in the NIDDM. Thus, a 5.6-fold higher $(P$ $<0.001)$ concentration of free insulin was needed to achieve a

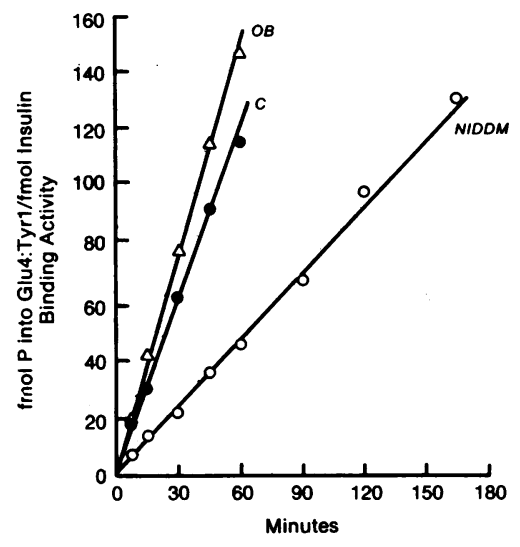

Figure 7. Time course of insulin-stimulated Glu4:Tyr1 phosphorylation. Aliquots $(40 \mathrm{fmol}$ insulin-binding capacity) of receptor preparations identical to those in Fig. $4 A$ were preincubated with $500 \mathrm{ng} / \mathrm{ml}$ insulin for $1 \mathrm{~h}$ at $4^{\circ} \mathrm{C}$ after which Glu4:Tyrl (final concentration $1.5 \mathrm{mg} /$ $\mathrm{ml}$ ) phosphorylation was measured for different periods of time. 


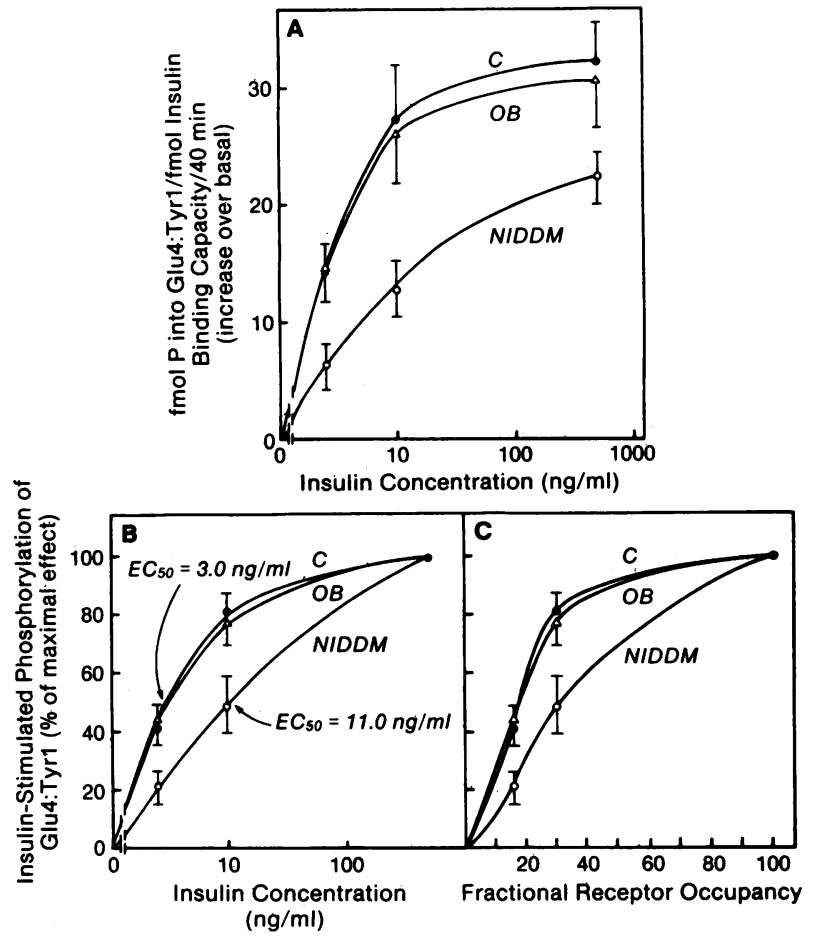

Figure 8. Insulin-stimulated phosphorylation of Glu4:Tyr1 by receptors from control, obese, and NIDDM subjects. Insulin receptors (28.5 fmol insulin-binding capacity $/ 30 \mu \mathrm{l}$ ) were preincubated with $0,2.5$, 10 , or $500 \mathrm{ng} / \mathrm{ml}$ unlabeled insulin in the absence or presence of 0.5 $\mathrm{ng} / \mathrm{ml}{ }^{125} \mathrm{I}$-insulin. Insulin binding and Glu4:Tyr1 phosphorylation were determined as noted in Methods. $(A)$ For each subject, basal Glu4:Tyr 1-phosphorylating activity was subtracted from corresponding insulin-stimulated values. The results (mean \pm SEM) were graphed as the increase over basal from 12 control (solid circle), 13 obese (open triangle), and 13 NIDDM (open circle) subjects. $(B)$ The kinase results in $(A)$ replotted as the percent of the effect achieved at $500 \mathrm{ng} / \mathrm{ml}$ insulin. $(C)$ The kinase results in $(B)$ recast as a function of fractional receptor occupancy as determined from the binding data.

half-maximal effect in the NIDDM relative to the controls. Among receptors with equal insulin binding affinity, as is the case in our three groups, free insulin concentration directly determines receptor occupancy. Expression of kinase data in terms of fractional receptor occupancy is a direct method for illustrating the effectiveness of bound insulin to stimulate Glu4:Tyr1 phosphorylation. To emphasize the coupling of insulin binding to insulin-stimulated phosphorylation of Glu4:Tyr 1, the kinase data of Fig. $8 \mathrm{~B}$ were also replotted as a function of fractional receptor occupancy. The results, shown in Fig. $8 \mathrm{C}$, demonstrated a halfmaximal effect at $18 \pm 3 \%$ occupancy in the controls, $19 \pm 3 \%$ in the obese nondiabetics, and $38 \pm 4 \%(P<0.001$ vs. controls or obese) in the NIDDM. Thus, in terms of occupancy, 2.1-fold more receptor-bound insulin was required to reach a half-maximal effect in the NIDDM group than in either the control or obese group.

Correlation analyses. We have previously shown that in some circumstances, autophosphorylation activity may differ from the kinase activity directed towards exogenous substrates (20). In the present study, both autophosphorylation and Glu4:Tyr 1 phosphorylation were reduced in NIDDM subjects relative to control and obese subjects. Furthermore, for individual subjects regardless of the experimental group, the magnitude of the effect

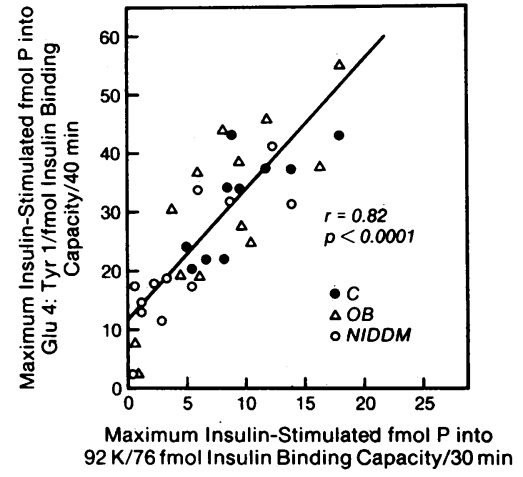

Figure 9. Correlation of insulin-stimulated autophosphorylation and insulin-stimulated Glu4: Tyrl phosphorylation. Individual data for máximally insulin-stimulated autophosphorylation (Fig. 5) and Glu4: Tyrl (Fig. 8 A) phosphorylation are plotted.

of insulin to promote autophosphorylation was highly correlated ( $r=0.85, P<0.001)$ with the insulin-induced increase in Glu4: Tyr1 phosphorylation as shown in Fig. 9. The amount of autophosphorylation, Glu4:Tyr1 phosphorylation, and insulin binding did not correlate significantly with fasting or integrated values of glucose and insulin measured during the OGTTs in the three groups, taken separately or combined.

Comparisons of the results of kinase activity in our three groups is potentially complicated by the fact that the obese and NIDDM subjects were both older and fatter than the control group. It is well documented that insulin resistance characterizes obesity (21-24) and NIDDM (24-26) as well as human aging $(48,49)$ (particularly in subjects over $60 \mathrm{yr}$ of age). Thus, the effect of age and obesity must both be taken into account when interpreting the kinase results of our NIDDM subjects. Clearly, obesity alone had no influence on receptor kinase activity, because the results were the same in the control and obese nondiabetic groups. The age of our control subjects was significantly less $(P<0.01)$ than the age of the obese nondiabetic subjects. Nonetheless, the receptor kinase activity was comparable in both groups at all insulin concentrations (Figs. 5 and 8). Moreover, within these two groups, taken separately or combined, neither age nor BMI correlated significantly with insulin-stimulated kinase activity. In an attempt to further address the issue of age, we compared the kinase activity in three obese subjects over 60 $\mathrm{yr}$ of age $(63.3 \pm 1.7 \mathrm{yr})$ with the results of those under $60 \mathrm{yr}$ $(40.4 \pm 2.8 \mathrm{yr})$ and found that the maximal insulin-stimulated Glu4:Tyr1 phosphorylation was $26.4 \pm 4.8$ and $31.3 \pm 5.5 \mathrm{fmol}$ phosphate/fmol insulin-binding activity/40 $\mathrm{min}(P, \mathrm{NS})$, respectively. Taken together, these findings suggest that within the range of age and BMI of subjects used for this study, neither age nor obesity were significant determinants of kinase activity. The effect of diabetes per se on insulin receptor kinase activity was more easily determined by comparing the kinase results of the obese and NIDDM subjects whose ages and BMIs were comparable. Between these two groups, the kinase activity was markedly different.

\section{Discussion}

In the current study, we have presented evidence that insulin receptor tyrosine kinase activity is markedly impaired in NIDDM. This defect in enzyme function of the receptor was observed using two different phosphoacceptors, the $\beta$ subunit (autophosphorylation) of the receptor and the synthetic substrate Glu4:Tyr1. Within the range of age and obesity in our study groups, these factors did not contribute to the kinase defect. 
Thus, our NIDDM subjects displayed a receptor kinase defect compared to age- and obesity-matched nondiabetic subjects, who in turn had values for intrinsic kinase activity equal to lean, younger controls. Because obese, nondiabetic subjects are insulin resistant (21-24), as are NIDDM subjects (24-26), it would appear that this postbinding defect in the intrinsic kinase activity of the insulin receptor is relatively specific for the hyperglycemic NIDDM state.

To strengthen this finding, we tried to exclude artifacts in the measurement of kinase activity. The reduction of kinase activity in NIDDM subjects could not be explained by ATPases or phosphatases, since under the conditions of our assays, the activities of these potential contaminants were negligible in all three groups. Moreover, it was unlikely that endogenous insulin, present in the fasting state in more than twice the concentration in NIDDM compared with controls, accounted for any difference in kinase activity since basal levels of autokinase and exogenous substrate phosphorylating activity were equal in all three groups. Furthermore, basal insulin levels in the NIDDM group were equivalent to those of the obese nondiabetic group despite marked differences in kinase results between the two groups. In interpreting the current receptor kinase results, it is important to recall that all of our phosphorylation studies were conducted with equal insulin-binding capacities for all subjects. Thus, the reduction in insulin-stimulated kinase activity in the NIDDM subjects resulted from an overall reduction in intrinsic kinase activity per receptor. Since the binding affinity of insulin was identical in all three groups, equivalent amounts of insulin were bound to receptors at each concentration of added insulin. Therefore, for an equal amount of bound insulin, insulin receptor kinase activity was markedly reduced in NIDDM, indicating that insulin binding is inefficiently coupled to the receptor kinase in NIDDM.

The cause for the reduced coupling efficiency in NIDDM is not yet clear. However, several explanations are possible. First, the ATP $K_{\mathrm{m}}$ for autophosphorylation and Glu4:Tyr1 phosphorylation could be higher for insulin receptors from NIDDM subjects. Since our assays were conducted at subsaturating concentrations of ATP, an increase in the ATP $K_{\mathrm{m}}$ would result in less phosphate transferred to phosphoacceptors. Second, receptors from NIDDM subjects could possess a structural or conformational alteration in the $\beta$ subunit that could either directly alter the active kinase site to reduce phosphate turnover or reduce available receptor phosphoacceptor sites critical for complete activation of the kinase. Recently, Burant et al. (18) demonstrated reduced kinase activity in association with an apparent posttranslational alteration in the structure of insulin receptors from skeletal muscles of rats made diabetic with streptozotocin. It is unlikely, however, that these types of structural alterations could be explained by proteolysis incurred during our receptor preparation because the isolation procedure, conducted at $4^{\circ} \mathrm{C}$, included proteolytic inhibitors and such modifications would have had to occur only in the NIDDM subjects, whose $\beta$ subunit had a molecular weight identical to that observed in the control and obese subjects. Another possible explanation for the reduced coupling efficiency in NIDDM is that the signal generated in the $\alpha$ subunit by the binding of insulin may be inadequately transmitted to the $\beta$ subunit so that incomplete activation of the receptor kinase occurs. Finally, the maximal amount of ${ }^{32} \mathrm{P}$ incorporated into a receptor preparation is a measure of the overall autophosphorylating capacity of the individual receptors. Thus, autophosphorylation may be reduced if all receptors have reduced kinase activity or the preparation contains subpopulations of receptors where some incorporate virtually no phosphate while other incorporate normal amounts. In this regard, we cannot exclude the possibility that the reduced autophosphorylation and Glu4:Tyr1 phosphorylation in receptors from NIDDM subjects is due to the presence of some receptors that bind insulin but have little, if any, kinase activity. Such a possibility could be due to preexisting phosphorylation of serine residues carried over from the in vivo state, as this has been shown to inhibit insulin stimulated receptor tyrosine kinase activity $(13,50)$.

The results of Glu4:Tyr 1 phosphorylation in the three groups suggest that an additional, and possibly more complex, form of reduced coupling may characterize the reduced kinase activity observed in NIDDM. In addition to the overall diminished ability of bound insulin to activate the receptor kinase, the results shown in Fig. 8 indicate that insulin bound at subsaturating concentrations activated the kinase less efficiently than insulin bound at maximally stimulating concentrations. The reason for this further uncoupling present at low insulin concentrations is unclear. Conceivably, insulin could cross-react with another tyrosine kinase at high, but not low, concentrations of insulin. As a consequence, Glu4:Tyr 1 phosphorylation measured at low concentrations of insulin would represent insulin receptor-mediated kinase activity, whereas phosphorylation of the peptide at saturating concentrations of insulin would be inappropriately high owing to the contribution from both kinases. This type of interaction would result in a shift to the right of the coupling curve. However, for several reasons this possibility seems remote. By far the most likely candidate for a receptor kinase of this sort is the IGF I receptor, which is known to phosphorylate Glu4: Tyr 1 (51) and can bind insulin when present in high concentrations $(51,52)$. However, adipocytes apparently lack IGF I receptors altogether (53). Other candidates for such a receptor kinase include the EGF $(54,55)$ and IGF II $(53)$ receptors. Although both of these receptor are present in adipocytes, neither binds insulin to any significant degree. Thus, it is unlikely that the uncoupling seen in Fig. $8 C$ is due to cross-reactivity of insulin with a tyrosine kinase separate from its own receptor. Instead, it is much more likely that the additional uncoupling is intrinsic to the insulin receptor itself. One possible explanation is the existence of different receptor subpopulations. Thus, a more extensive degree of uncoupling in the receptors occupied at low concentrations of insulin (high-affinity receptors) than in those occupied at high concentrations of insulin (low-affinity receptors) could explain the results. Recently, Heffetz et al. showed that receptor aggregation may play a role in activating the receptor kinase (56). A greater reduction in receptor aggregation at low insulin concentrations could also explain the results. It is not clear why the uncoupling seen in Fig. $8 C$ was not also observed for the autophosphorylation results.

The amount of insulin-stimulated Glu4:Tyr1 phosphorylation catalyzed by a receptor was highly correlated to its degree of insulin-stimulated autophosphorylation, regardless of the experimental group (Fig. 9). In the reaction used to measure Glu4: Tyr 1 phosphorylation, autophosphorylation, which supposedly serves to activate the insulin receptor kinase toward the exogenous substrate Glu4:Tyr 1 (7-10), proceeds simultaneously with phosphorylation of the peptide. Thus, it is possible that the Glu4: Tyr 1 kinase activity is reduced in NIDDM as a consequence of the reduction in autophosphorylation. Because some or all of the tyrosine autophosphorylation of the $\beta$ subunit is related to activation of the kinase toward exogenous substrates, one might 
then expect to see an increase in the rate of Glu4:Tyr1 phosphorylation over time, particularly in NIDDM receptors, as sites on the $\beta$ subunit critical for enhanced kinase activity progressively autophosphorylate. In parallel studies, measuring rates of autophosphorylation (Fig. $4 \mathrm{~A}$ ) and Glu4:Tyr1 phosphorylation (Fig. 7) over prolonged periods of time in the three groups, we found a reduction in the maximal insulin-stimulated phosphorylation of the $\beta$ subunit in NIDDM subjects relative to the control and obese subjects. However, the sites necessary for activation of the kinase appeared to phosphorylate rapidly since the time course of Glu4:Tyrl phosphorylation did not depart from linearity. The rate of Glu4:Tyr1 phosphorylation remained linear in the NIDDM subjects even when measured after 120 min, when maximal autophosphorylation had occurred in all three groups. Furthermore, the amount of autophosphorylation at $120 \mathrm{~min}$ in the NIDDM group was equal to the amount of autophosphorylation in the obese and controls at $\sim 15 \mathrm{~min}$. Nevertheless, the rate of Glu4:Tyr 1 phosphorylation, from 120 $165 \mathrm{~min}$ in the NIDDM group, was still decreased compared with that measured in the control and obese groups over an equivalent 45-min period of time from 15-60 min. Thus, even starting with equal amounts of autophosphorylation, the subsequent rate of Glu4:Tyr1 phosphorylation was still decreased in NIDDM subjects, indicating that the reduction in Glu4:Tyr 1 phosphorylation in NIDDM was not secondary to decreased autophosphorylation. Rather, the findings reinforce our conclusion that NIDDM receptors have reduced insulin-stimulated kinase activity due to a reduction in the coupling efficiency of insulin binding to activation of the kinase.

Obese nondiabetic subjects are insulin resistant, as are NIDDM subjects. We have previously shown that the major cause of insulin resistance in both obesity and NIDDM involves postbinding defects in insulin action (24). However, the sites of these defects may differ in the two conditions (33). In this regard, the current studies show a postbinding defect in intrinsic receptor kinase activity that appears to be relatively specific for NIDDM and not obesity. This represents the earliest postbinding event recognized so far in NIDDM. Furthermore, since activation of the receptor kinase is the earliest known postbinding step in insulin action, the potential relevance of a defect in kinase activity to the etiology of insulin resistance in the NIDDM state is obvious. Thus, insofar as receptor kinase activity mediates insulin's ultimate biologic effects, the kinase defect in NIDDM could underly some or all of the postbinding aspects of insulin resistance in this condition.

Whether the kinase defect observed in the NIDDM group is primary or secondary is presently unknown. Clearly insulin receptor kinase defects can be acquired as shown by the development of altered receptor kinase activity secondary to streptozotocin diabetes (17), dietary manipulations in rats (20), and progressive obesity with hyperglycemia in mice (19). The cause of these acquired defects is unknown, but potential factors that could be involved are obesity and prevailing levels of insulin and glucose. In humans, the degree of obesity does not correlate with the development of decreased kinase activity because obese and NIDDM subjects had similar BMIs but markedly different kinase activities. The role of hyperinsulinemia and hyperglycemia per se in the development of altered kinase activity is unclear $(19,20,57)$. Studies in NIDDM subjects before and after treatment and/or in fibroblasts cultured from these patients will help resolve the question of whether the kinase defect in NIDDM is acquired.
It is possible that the kinase defect in the NIDDM group reflects a subtle alteration in protein structure of the NIDDM insulin receptor, at least in some patients. In this event the kinase defect would be genetic rather than acquired. The tendency toward NIDDM is a familial trait whose expression is influenced by a variety of dietary and environmental factors. Thus, it is possible that a defect in kinase activity may be related to a primary genetic defect in the insulin receptor gene. Since the insulin receptor gene has recently been cloned and sequenced (5), it is now possible to determine whether abnormalities of the gene exist and whether they are important in the development of NIDDM.

Insulin-stimulated tyrosine kinase activity has been found in insulin receptors extracted from a variety of cell and tissue types $(8,10,16,18-20,44,45,57)$, however, to date there have been no reports characterizing the insulin receptor kinase of human adipocytes. We have observed that, like the insulin receptor kinase described for other cells, insulin stimulated a 1012 -fold increase in tyrosine phosphorylation of the $\beta$ subunit of the receptor from human adipocytes in a dose and time-dependent fashion with a half-maximal effect achieved at $1-3 \mathrm{ng} / \mathrm{ml}$ free insulin. The time course of autophosphorylation proceeded 5-6 times more slowly in receptors derived from human adipocytes than in receptors from rat liver under identical phosphorylation conditions (20). A similar time course was observed in receptors from all three experimental groups. The reason for and the significance of this slower time course in human adipocytes is unknown.

\section{Acknowledgments}

The authors wish to thank Cleon Tate and Elizabeth Martinez for their skillful preparation of this manuscript.

Dr. Klein is supported by a fellowship of Deutsche Forschungsgemeinschaft. This work was supported in part by grants AM-07494, AM33650, and AM-33651 from the National Institutes of Health.

\section{References}

1. LeCam, A. 1982. Insulin and glucagon regulation of protein phosphorylation in isolated hepatocytes: persistence, reversibility, and concentration dependence of hormonal effect. Evidence for common phosphorylation sites for both hormones on the $\mathrm{Mr}=45,000$ protein. J. Biol. Chem. 257:8376-8385.

2. Avruch, J., M. C. Alexander, J. L. Palmer, M. Pierce, R. A. Nemenoff, P. J. Blackshear, J. P. Tipper, and L., A. Witters. 1982. Role of insulin-stimulated protein phosphorylation in insulin action. Fed. Proc. 41:2629-2633.

3. Avruch, J., R. A. Nemenoff, M. Pierce, Y. C. Kwok, and P. J. Blackshear. 1985. Protein phosphorylations as a mode of insulin action. In Molecular Basis of Insulin Action. M. P. Czech, editor. Plenum Publishing Corp., New York. 263-296.

4. Kasuga, M., J. A. Hedo, K. M. Yamada, and C. R. Kahn. 1982. The structure of insulin receptor and its subunits: evidence for multiple nonreduced forms and a 210,000 possible proreceptor. J. Biol. Chem. 257:10392-10399.

5. Ullrich, A., J. R. Bell, E. Y. Chen, R. Herrera, L. M. Petruzelli, T. J. Dull, A. Gray, L. Coussens, Y.-C. Liao, M. Tsubokawa, A. Mason, P. H. Seeburg, C. Grunfeld, O. M. Rosen, and J. Ramachandran. 1985. Human insulin receptor and its relationship to the tyrosine kinase family of oncogenes. Nature (Lond.). 313:756-761.

6. Kasuga, M., F. A. Karlsson, and C. R. Kahn. 1982. Insulin stimulates the phosphorylation of the 95,000-dalton subunit of its own receptor. Science (Wash. DC). 215:185-187. 
7. Rosen, O. M., R. Herrera, Y. Olowe, L. M. Petruzelli, and M. H. Cobb. 1983. Phosphorylation activates the insulin receptor tyrosine protein kinase. Proc. Natl. Acad. Sci. USA. 80:3237-3240.

8. Yu, K.-T., and M. P. Czech. 1984. Tyrosine phosphorylation of the insulin receptor $\beta$-subunit activates the receptor-associated tyrosine kinase activity. J. Biol. Chem. 259:5277-5286.

9. Nemenoff, R. A., Y. C. Kwok, G. I. Shulman, P. J. Blackshear, R. Osathanondh, and J. Avruch. 1985. Insulin-stimulated tyrosine protein kinase: characterization and relation to the insulin receptor. J. Biol. Chem. 259:5058-5065.

10. Klein, H. H., G. R. Freidenberg, M. Kladde, and J. M. Olefsky. 1986. Insulin activation of insulin receptor tyrosine kinase in intact rat adipocytes: an in vitro system to measure histone kinase activity of insulin receptors activated in vivo. J. Biol. Chem. 261:4691-4697.

11. Maller, J. L., L. J. Pike, G. R. Freidenberg, R. Cordera, B. J. Stith, J. M. Olefsky, and E. G. Krebs. 1986. The phosphorylation of ribosomal protein S6 is increased following microinjection of insulin receptor-kinase into Xenopus oocytes. Nature (Lond.). 320:459-461.

12. White, M. F., S. Takayama, and C. R. Kahn. 1985. Differences in the sites of phosphorylation of the insulin receptor in vivo and in vitro. J. Biol. Chem. 260:9470-9478.

13. Pang, D. T., B. R. Sharma, J. A. Shafer, M. F. White, and C. R. Kahn. 1985. Predominance of tyrosine phosphorylation of insulin receptors during the initial response of intact cells to insulin. J. Biol. Chem. 260:7131-7136.

14. Grunberger, G., Y. Zick, and P. Gordon. 1984. Defect in phosphorylation of insulin receptors in cells from an insulin-resistant patien with normal insulin binding. Science (Wash. DC). 223:932-934.

15. Grigorescu, F., J. S. Flier, and C. R. Kahn. 1984. Defect in insulin receptor phosphorylation in erythrocytes and fibroblasts associated with severe insulin resistance. J. Biol. Chem. 259:15003-15006.

16. Grigorescu, F., J. S. Flier, and C. R. Kahn. 1986. Characterization of binding and phosphorylation defects of erythrocyte insulin receptors in the Type A syndrome of insulin resistance. Diabetes. 35:127-138.

17. Kadowaki, T. M., M. Kasuga, Y. Akanuma, O. Ezaki, and F. Takaku. 1984. Decreased autophosphorylation of the insulin receptor kinase in streptozotocin-diabetic rats. J. Biol. Chem. 259:14208-14216.

18. Burant, C. F., M. K. Treutelaar, and M. G. Buse. 1986. Diabetesinduced functional and structural changes in insulin receptors from rat skeletal muscle. J. Clin. Invest. 77:260-270.

19. LeMarchand-Brustel, Y., T. Gremeaux, R. Ballotti, and E. van Obberghen. 1985. Insulin receptor tyrosine kinase is defective in skeletal muscle of insulin-resistant obese mice. Nature (Lond.). 315:676-679.

20. Freidenberg, G. R., H. H. Klein, R. Cordera, and J. M. Olefsky. 1985. Insulin receptor kinase activity in rat liver: regulation by fasting and high carbohydrate feeding. J. Biol. Chem. 260:12444-12453.

21. Harrison, L. C., and A. P. King-Roach. 1976. Insulin sensitivity of adipose tissue in vitro and the response to exogenous insulin in obese human subjects. Metabolism. 25:1095-1101.

22. Kolterman, O. G., J. Insel, M. Saekow, and J. M. Olefsky. 1980. Mechanisms of insulin resistance in human obesity. J. Clin. Invest. 65: 1271-1284.

23. Rabinowitz, D., and K. L. Zierler. 1962. Forearm metabolism in obesity and its response to intra-arterial insulin. J. Clin. Invest. 41: 2173-2181.

24. Olefsky, J. M. 1981. Insulin resistance and insulin action. An in vitro and in vivo perspective. Diabetes. 30:148-162.

25. Kolterman, O. G., R. Gray, J. Griffin, P. Bernstein, J. Insel, J. Scarlett, and J. Olefsky. 1981. Receptor and postreceptor defects contribute to the insulin resistance in non-insulin dependent diabetes mellitus. J. Clin. Invest. 68:957-969.

26. Rizza, R. A., L. J. Mandarino, and J. E. Gerich. 1981. Mechanism and significance of insulin resistance in non-insulin-dependent diabetes mellitus. Diabetes. 30:990-995.

27. Bogardus, C., S. Lillioja, K. Stone, and D. Mott. 1984. Correlation between muscle glycogen synthase activity and in vivo insulin action in man. J. Clin. Invest. 73:1 185-1190.
28. Kashiwagi, A., M. Verso, J. Andrews, B. Vasquez, G. Reaven, and J. Foley. 1983. In vitro insulin resistance of human adipocytes isolated from subjects with non-insulin-dependent diabetes mellitus. J. Clin. Invest. 75:1246-1254.

29. Evans, D. J., R. Murray, and A. H. Kissebah. 1984. Relationship between skeletal muscle insulin resistance, insulin-mediated glucose disposal, and insulin binding: effects of obesity and body fat topography. J. Clin. Invest. 74:1515-1525.

30. Armoni, M., R. Rafaeloff, A. Barzilai, and E. Karnielli. 1985. A possible mechanism of insulin resistance in human adipose and adipose cells: depletion of the intracellular pool of glucose transporters. Diabetes. 34:82a. (Abstr.)

31. Pedersen, O., E. Hjollund, and N. S. Sorensen. 1982. Insulin receptor binding and insulin action in human fat cells: effects of obesity and fasting. Metabolism. 31:884-895.

32. Ciaraldi, T., O. Kolterman, and J. Olefsky. 1981. Mechanism of the postreceptor defect in insulin action in human obesity. J. Clin. Invest. 68:875-880.

33. Mandarino, L., P. Campbell, and J. Gerich. 1984. Abnormal coupling of insulin receptor binding in noninsulin-dependent diabetes. Am. J. Physiol. 247:E688-E692.

34. National Diabetes Data Group. 1979. Classification and diagnosis of diabetes mellitus and other categories of glucose intolerance. Diabetes. 28:1039-1057.

35. Desbuquois, B., and G. D. Aurbach. 1971. Use of polyethylene glycol to separate free and antibody-bound peptide hormones in radioimmunoassays. J. Clin. Endocrinol. Metab. 33:732-738.

36. Olefsky, J. M. 1976. Decreased insulin binding to adipocytes and circulating monocytes from obese subjects. J. Clin. Invest. 57:1 165-1172.

37. Rodbell, M. 1964. Metabolism of isolated fat cells. I. Effects of hormones on glucose metabolism and lipolysis. J. Biol. Chem. 239:375380.

38. Bradford, M. M. 1976. A rapid and sensitive method for the quantitation of microgram quantities of protein utilizing the principle of protein-dye binding. Anal. Biochem. 72:248-254.

39. Klein, H. H., G. R. Freidenberg, R. Cordera, and J. M. Olefsky. 1985. Substrate specificities of insulin and epidermal growth factor receptor kinases. Biochem. Biophys. Res. Comm. 127:254-263.

40. Johnson, R. A., and T. F. Walseth. 1979. The enzymatic preparation of $\left[\gamma-{ }^{32} \mathrm{P}\right] \mathrm{ATP},\left[\gamma-{ }^{32} \mathrm{P}\right] \mathrm{GTP},\left[{ }^{32} \mathrm{P}\right] \mathrm{cAMP}$, and $\left.{ }^{32} \mathrm{P}\right] \mathrm{CGMP}$, and their use in the assay of adenylate and guanylate cyclases and cyclic nucleotide phosphodiesterases. Adv. Cyclic Nucleotide Res. 10:135-167.

41. Berhanu, P., O. G. Kolterman, A. Baron, P. Tsai, J. M. Olefsky, and $D$. Brandenburg. 1983. Insulin receptors in isolated human adipocytes: characterization by photoaffinity labeling and evidence for internalization and cellular processing. J. Clin. Invest. 72:1958-1970.

42. Olefsky, J. M., and G. M. Reaven. 1974. Decreased insulin binding to lymphocytes from diabetic patients. J. Clin. Invest. 54:1323-1328.

43. DeFronzo, R. A., D. Diebert, R. Hendler, and P. Felig. 1979. Insulin sensitivity and insulin binding to monocytes in maturity-onset diabetes. J. Clin. Invest. 63:939-946.

44. White, M. F., H.-U. Haring, M. Kasuga, and C. R. Kahn. 1984. Kinetic properties and sites of autophosphorylation of the partially purified insulin receptor from hepatoma cells. J. Biol. Chem. 259:255-264.

45. Zick, Y., M. Kasuga, C. R. Kahn, and J. Roth. 1983. Characterization of insulin-mediated phosphorylation of the insulin receptor in a cell-free system. J. Biol. Chem. 258:75-80.

46. Swarup, G., S. Cohen, and D. L. Garbers. 1982. Inhibition of membrane phosphotyrosyl-protein phosphatase activity by vanadate. Biochem. Biophys. Res. Comm. 107:1104-1109.

47. Zick, Y., J. Whittaker, and J. Roth. 1983. Insulin stimulated phosphorylation of its own receptor: activation of a tyrosine-specific protein kinase that is tightly associated with the receptor. J. Biol. Chem. 258:3431-3434.

48. Fink, R. I., O. G. Kolterman, J. Griffin, and J. M. Olefsky. 1983. Mechanisms of insulin resistance in aging. J. Clin. Invest. 71:1523-1535.

49. Lannroth, P., and U. Smith. 1986. Aging enhances the insulin 
resistance in obesity through both receptor and postreceptor alterations. J. Clin. Endocrinol \& Metab. 62:433-437.

50. Takayama, S., M. F. White, V. Lauris, and C. R. Kahn. 1985. Phorbol esters modulate insulin receptor phosphorylation and insulin action in cultured hepatoma cells. Proc. Natl. Acad. Sci. USA. 81:77977801 .

51. Zick, Y., N. Sasaki, R. W. Rees-Jones, G. Grunberger, S. P. Nissley, and M. M. Rechler. 1984. Insulin like growth factor-I (IGF-I) stimulates tyrosine kinase activity in purified receptors from a rat liver cell line. Biochem. Biophys. Res. Comm. 119:6-13.

52. Kasuga, M., N. Sasaki, C. R. Kahn, S. P. Nissley, and M. M Rechler. 1983. Antireceptor antibodies as probes of insulin like growth factor receptor structure. J. Clin. Invest. 72:1459-1469.

53. Massague, J., and M. P. Czech. 1982. The subunit structures of two distinct receptors for insulin-like growth factors I and II and their relationship to the insulin receptor. J. Biol. Chem. 257:5038-5045.

54. Pessin, J. E., W. Gitomer, Y. Oka, C. L. Oppenheimer, M. P. Czech. 1983. $\beta$-adrenergic regulation of insulin and epidermal growth factor receptors in rat adipocytes. J. Biol. Chem. 258:7386-7394.

55. O'Keefe, E., M. D. Hollenberg, and P. Cuatrecasas. 1974. Epidermal growth factor: characteristics of specific binding in membranes from liver, placenta, and other target tissues. Arch. Biochem. Biophys. 164:518-526.

56. Heffetz, D., and Y. Zick. 1986. Receptor aggregation is necessary for activation of the soluble insulin receptor kinase. J. Biol. Chem. 261: 889-894.

57. Arsenis, G., and J. N. Livingston. 1986. Alterations in the tyrosine kinase activity of the insulin receptor produced by in vitro hyperinsulinemia. J. Biol. Chem. 261:147-153. 